DOI: 10.19085/journal.sijmas030902

\title{
Youth Radicalization in Africa: A Comparative Analysis of Radicalized Groups
}

\author{
Rono Kiplangat Kenneth \& Christopher Omusula
}

Kenyatta University, Kenya.

๑ Scholedge International Journal of Multidisciplinary \& Allied Studies (ISSN 2394-336X), Vol.03, Issue 09 (2016) pg185-196.

Published by: Scholedge R\&D Center [http://www.thescholedge.org/journals/] [Email: editorial@thescholedge.org]

\begin{abstract}
A lot of efforts are being exerted by world's governments and other stakeholders to achieve higher rates of Accessibility to Education. Militia groups the world over have recruited and radicalized the potential school going children into their militant outfits to either fight in battlefields, or use them as spies or suicide bombers denying them opportunities of accessing education that would have been very valuable in their development. These groups abduct torture and kill victims, cause untold sufferings of their captives. In Africa, BokoHaramu in Nigeria opposes modern formal education and hinders the youth from accessing benefits associated with formal education they kidnap students from schools, women from market places, rape and force them into marriages. Mungiki in Kenya has caused school enrolment in central Kenya to drop. Their forced initiations into the groups, doctrines and practice or threat of Female Genital Mutilations, the taking of drugs and the insecurity caused by the sect members are the major challenges the Kenyan Nation is facing as a threat to realization of the objectives of vision 2030 in its former Central Province. The groups, in their teachings, associate formal education with neo-colonialism or western imperialism. Al-Shabab enforces its own harsh interpretation of sharia law, prohibiting various types of entertainment, such as movies and music, the sale of khat, smoking, the shaving of beards, and many other "un-Islamic" activities. This paper examines historical and Philosophical backgrounds of some of the militia groups in Africa such as Al-Shabab in Somalia, Boko Haram in Nigeria and Mungiki in Kenya. Highlighting modes of recruitment, radicalization and how school aged youths are utilized by militia groups. The paper argues that use of strategies such as military force in Nigeria on Boko Haram has failed to bear any fruits. It suggests that skewed distribution of national educational funds could be an impetus to forces of radicalization of youth. Therefore, this paper suggests strategies that can be used to counter the recruitment and radicalization of youths in an effort to improve Educational Access and Equity in Africa.
\end{abstract}

Key Words:Educational, Militia Groups, Radicalization, Recruitment, School-aged Youth

\section{Introduction}

Throughout history, school-aged youth have participated in a variety of organizations that promote or carry out acts of violence. (Demhardt, 1990).Youths have helped to fill the ranks of militant groups. Young 
persons' roles within these organizations have varied, from providing logistical support, serving as "lookouts" or "mules," raising funds, taking part in battles, or carrying out attacks. (Draper, Spierenburg , 2004). The process by which youth become involved in these groups also varies, with some being born into radical environments that promote violence, some being "spotted" and directly recruited by groups, some self-selecting into the group, and others being forced into membership(Demhardt, 1990).Currently the identified militia groups that are involved in youth radicalization are the Hamas,Hizballah,Jemaah Islamiyahand Al-Qaeda and its affiliated groups. These groups are primarily active in Afghanistan, Pakistan, Iraq and the United Kingdom. They are also spread over Turkey, Iraq, Iran, Nepal, Thailand, Palestine, Lebanon, Colombia, Somalia, Philippines, Japan, Sri Lanka, Peru, Bosnia, Africa, \& Western Europe. (Gaomas, 2006).However, this paper discussesYouth Radicalization in Africa.

In Kenya all boys, girls and adolescents have the right to education to allow them to develop their potential and capabilities (GOK, 2012). The Ministry of Education is the institution responsible for guaranteeing access to free basic education (primary and secondary education), including vocational training for all adolescents. Children are supposed to get educated irrespective oftheir differences in personal or social circumstances such as religion, gender, ethnic origin or family background, there should be no obstacles to achieving educationalpotential and that all individuals reach at least a basic minimum level of skills through inclusion policy.(Hammelburg, 2006). Hammelburg asserts that the effect of militia groups totally curtail development of educational potential of the young generations to come.Their interferencewith school system through creation of insecurity and anxiety in their areas of operations have diverted youth from pursuing education agenda. In effect, their activities pose a big threat to realization of universal access to educationby the young generations of today.(Hanks, 2001).

\section{Theoretical Framework (Dalgaard Nelson, 1940)}

This paper utilizes FramingTheory byDalgaard Nelson, (1940)which is one of the Social Mobilization Theories. Framing Theory focuses on how movements and social groups construct, produce, and disseminate meanings. This is a recursive process in which the movement's idea attempts to frame messages in ways that best resonates with the interests, attitudes, and beliefs of its potential members. Then, as people accept the movement's idea, they increasingly come to identify themselves with the movement. The theory postulates that firstly,movements diagnose problems and attribute them to a failing society. Secondly, they attempt to offer solutions, strategies, and tactics (prognostic framing) and provide motivational frames to convince potential participants to become diehard members of the movement. This Theory can be useful in understanding radicalization process as emanating from the weak societal fabric that hold the norms and practices within the society in question. This theory helps to understand an in depthprocesses of radicalization movements in Africa.(Alkande, et al., 2005).

\section{Children's Have a Right to Access Education}

Children's right to access education in areas occupied by militant groups has severely declined. According to UNICEF Report, (2010), Somalia has one of the lowest rates of school enrollment in the world, with a net primary enrolment of $21 \%$ and transitional school enrollment rate of around $23 \%$ in 2010 . Disparity between levels of enrollment between girls and boys even at the lower levels of primary school is alarming: 
according to the latest available data, the gross primary enrollment ratio is only $23 \%$. Enrollment in secondary schools is minimal, gross secondary enrollment is only $11 \%$ for boys and $5 \%$ for girls in 2014 . School dropout rates reportedly reached $50 \%$ following the Ramadan offensive in2010 and 38\% in the first four months of 2011. (Hentz, 2004).

The recruitment and use of children byAl Shabaabis a common practice phenomenon: children have been used throughout the conflict by clan and warlord militias for the defense of the home and the clan. However, the level of recruitment and radicalization of children by Al Shababhas substantially increased since early 2007 when recruitment became more widespread. Militia in Somalia al-Shabaab,Hizbul Islam, and AhluSunnaWalJama'a who have recruited or used children for military service. Girls and boys have both been targeted, with girls taken primarily for domestic duties and boys taken to be trained for combat or other work on the front lines. In former Kenya frontier districts (Wajir and Mandera), the ever-present reality of forced recruitment and abduction has caused children to leave school, often fleeing the counties with their families. Children are afforded multiple special protections under the international human rights and humanitarian law framework. International humanitarian law prohibits any recruitment of children under the age of 15 or their participation in hostilities by national armed forces and non-state armed groups. (International Humanitarian Law, 2005).Al-Shabaab forces took children to their training camps throughout 2010 and 2014. Most of the children were reportedly between ages 15 and 18 but some were as young as 10 years old. From the camps they were sent to the front lines in war fields. It is against this background that the researcher sought to study the Effects of Youth Radicalization on Accessibility in Education with a view of suggesting other strategies that can be used to counter the recruitment and radicalization of young persons with ultimate goal of improving their access to education. (Held, Mcgrew, Goldblatt\&Perraton, 1999)

\section{Contexts and Tactics Used In Recruitment of Youths into Radical Militias}

This study attempts to examine how some militant groups are recruiting, radicalizing, and utilizing schoolaged youth. It is necessary to get a more comprehensive understanding of youth radicalization and to share this knowledge with community members who come in contact with young persons on a regular basis, including educators, parents, and religious leaders. Educating these individuals will enable them to better address the needs of young persons and to identify and prevent potential problems. Given the apparent increase of youth involvement in militant organizations, and the changing demographics of those involved or implicated, it is necessary to promote greater awareness that young persons are susceptible to militia groups' recruitment and radicalization. (Held, Mcgrew, Goldblatt\&Perraton, 1999).Any young person with access to an Internet connection can view websites that promote militant groups or provide graphic depictions of acts of terrorism that are commonly portrayed as acts of heroism.

\section{Historical and Philosophical Backgrounds of Radicalizing Militias}

Al-Shabab and Boko Haram Militia Groups ideology is premised on an extreme Islamic teaching that rejects most Western ideas and institutions as un-Islamic while Mungiki Militia Group favor a return to indigenous African traditions. They reject westernization and all things that they believe to be trappings of colonialism, including Christianity. The ideology of the group is characterized by revolutionary rhetoric, Kikuyu traditions, and a disdain for Kenyan modernization which is seen as immoral corruption. Mungiki is 
often referred to as Kenya's Mafia due to its organization. They have been newsworthy for associations with ethnic violence and anti-government resistance.(Nyong'o, 1990).

Al-Shabab, or "The Youth," is an al-Qaida-linked militant group and U.S: - designated Foreign Militant Organization fighting for the creation of a fundamentalist Islamic state in Somalia. The group, also known as Harakat al-Shabab al-Mujahideen, and its Islamist affiliates once held sway over Mogadishu and major portions of the Somali countryside, but a sustained African Union military campaign in recent years has weakened the group considerably. Still, security analysts warn that the group remains the principal threat in a politically volatile, war-torn state. (Hentz, 2004).

Somalia, one of the most impoverished countries in the world, has seen a number of radical Islamist groups come and go in its decades-long political tumult. According to Hanks, (2001), analysts cite al-Shabab as a precursor, and the incubator for many of its leaders, like Al-Ittihad Al-Islami (aka Unity of Islam), a militant Salafi extremist group that peaked in the 1990s after the fall of the SiadBarre military regime (1969-1991) and the outbreak of civil war. (Alkande, et al., 2005),

AIAI, which sought to establish an Islamist emirate in Somalia, sprang from a band of Middle Easterneducated Somali extremists and was partly funded and armed by al-Qaida chief Osama bin Laden. Many of its fighters, including current Al-Shabab commanders, fled the country and fought in Afghanistan in the late 1990 s after being pushed out by the Ethiopian army and its Somali supporters. The group was designated a militant organization by the U.S. State Department in the days after the September 11, 2001 attacks.

In areas it controls, al-Shabab enforces its own harsh interpretation of Sharia Law, prohibiting various types of entertainment, such as movies and music, the sale of Khat (a narcotic plant often chewed), smoking, the shaving of beards, and many other "un-Islamic" activities. Stoning and amputations have been meted out as punishment on adulterers and thieves. According to international rights groups, alShabab often kidnaps young boys from school and forces them to fight and die in battle. (Gaomas, 2006).

The group also violently persecutes non-Muslims, including Christians, and is a major threat to humanitarian and other international workers, according to the U.S. State Department. Several beheadings of so-called apostates have been recorded. Al-Shabab also is known to have desecrated the graves of those from other religious groups, including moderate Islamic clerics.

Boko Haram's official name is Jama'atuAhlisSunnaLidda'awatiwal-Jihad, which in Arabic means "People Committed to the Propagation of the Prophet's Teachings and Jihad". Loosely translated from the region's Hausa language, this means "Western education is forbidden". The group was founded in 2002. Its Official Arabic name is Jama'atuAhlisSunnaLidda'awatiwal-Jihad, meaning "People Committed to the Propagation of the Prophet's Teachings and Jihad". Boko originally meant fake but came to signify Western education, while haram means forbidden. It initially focused on opposing Western education, but later launched military operations in 2009 to create Islamic state. It was designated as a militant group by US in 2013. 
Boko Haram promotes a version of Islam which makes it "haram", or forbidden, for Muslims to take part in any political or social activity associated with Western society,(Nyong'o, 1990).This includes voting in elections, wearing shirts and trousers or receiving a secular education. Boko Haram regards the Nigerian state as being run by non-believers, even when the country had a Muslim president - and it has extended its military campaign by targeting neighboring states. It has attacked many schools in northern Nigeria. The group launched its insurgency in 2009 with targets being both civilians and the military. It was founded by Mohammed Yusuf who was killed in police custody in 2009 and since then there has been resistance among some of the area's Muslims to Western education. They still refuse to send their children to government-run "Western schools", a problem compounded by the ruling elite who see education as a priority. Against this background, the charismatic cleric Mohammed Yusuf formed Boko Haram in Maiduguri in 2002. He set up a religious complex, which included a mosque and an Islamic school. Many poor Muslim families from across Nigeria, as well as neighboring countries, enrolled their children at the school. Boko Haram was not interested in education. Its goal was to create schools as recruiting grounds for jihadis,(Draper, et al., 2004).

In 2009, Boko Haram carried out a spate of attacks on police stations and other government buildings in Maiduguri, capital of Borno state. This led to shoot-outs on Maiduguri's streets. Hundreds of Boko Haram supporters were killed and thousands of residents fled the city,(Clapham, 2001). Nigeria's security forces eventually seized the group's headquarters, capturing its fighters and killing Yusuf... its leader. His body was shown on state television and the security forces declared Boko Haram finished. But its fighters regrouped under a new leader, AbubakarShekau, stepped up their insurgency. Their trademark is the use of gunmen on motorbikes, killing police, politicians and anyone who criticize them, including clerics from other Muslim traditions and Christian preachers. The group targets Churches, Schools, Markets, Bus Parks, Bars, Military Barracks and even the police and UN headquarters in the capital, Abuja.

The group's fighters launch mass attacks on villages and towns, looting, killing, abducting women and children from schools and conscripting men and boys into their army. In February 2012, Boko Haram members burned down three schools in the town of Maiduguri in north-eastern Nigeria. The group claimed that the attack was provoked by indiscriminate student arrests in Islamic schools by state forces (IRIN, 2013). In April 2014, they abducted more than 200 schoolgirls from Chibok town in Borno state, saying it would treat them as slaves and marry them off - a reference to an ancient Islamic belief that women captured in conflict are considered war booty.

In this instance, schools become sites of retaliation against government actions perceived as repressive by non-state actors. The fact that some militant groups expressly kill innocent pupils is telling of how school and educational sites are political instruments in the eyes of some armed groups. (IRIN, 4 October 2013). A report by Amnesty documents that between 2010 and 2011, attacks carried out against schools were mostly conducted when they were unoccupied (Amnesty International, 3rd October, 2013). The consequences of attacks would have been beyond imaginations if they would have found students in those schools.Schools are seen as instruments of the state and are often used as political leverage to achieve political goals through disruption, and intentional killing of innocent teachers and pupils. Violations against schools and students are most prevalent in Nigeria, Kenya, Sudan, Zimbabwe and Somalia 
Boko Haram and Al Shabaab are the most active actors in school-directed violence. Boko Haram have been involved in 33\% conflict events involving schools since 1997. They destroy school property, signifying the symbolic nature of their insurgency and their opposition to Western forms of education. UNESCO reported a "substantial negative impact on educational attainment during periods of conflict" in Somalia, with a decline in the average years of formal schooling achieved. (UNESCO, 2010) Protracted violence from within and outside of schools, as well as varying tactics employed by Boko Haram has created problematic societal issues in Nigeria's education in terms of access and. The threat Boko Haram poses will disappear only if Nigeria's government manages to reduce the region's chronic poverty and builds an education system which gains the support of local Muslims, (Draper et al., 2004).

The presence of and activities of militant groups may be an important factor in the ability and willingness of the youth to fully participate and therefore, gain from formal education. Such groups may hinder the youth from acknowledging that education has been identified as among the main factors in socioeconomic success (Datta, 1984). Though the government and other stakeholders may take appropriate steps to ensure that the youth get access to basic education, other forces may hinder the realization of this goal. The learner must be intrinsically and extrinsically motivated to desire to participate in formal education in order to gain from it. If obstacles and distracters are erected on the path of the learner, then the desire to access and participate in education will get diminished. (Ghai, 2003).

Mungiki Militia is based in the former central province of Kenya. The nameMungiki means "A united people" or "multitude" in the in kikuyu language. The religion, which apparently originated in the late 1980 s, is secretive and bears some similarity to a mystery religion whose doctrines are unclear. Threats of violence and fundamentalist activism by Mungiki are bad for education. (Ghai, 2003), Recruitment of the youth into such sects that do not rate Western Education is even worse. This is because all these become obstacles and detractors to the youth's ability to access education. According to Sifuna et al., (2006), conflict theorists rightly contend that any upheavals in the society will negatively affect education. The mungiki, with roots in former Central Province, Rift Valley and Nairobi among other areas, is a fierce opponent of what it calls western education. The Sect maintains that the Kikuyu should abandon Christianity and western education and revert to Kikuyu traditional beliefs and practices (Wamue, 2001). The Sect's ideologies and activities therefore hinder the youth from accessing the benefits of modern education. it is estimated that at the height of its influence, the group could claim as many as 500,000 potential school going youths who received substantial sums of money from politicians. (Sifuna et al., 2006),

\section{How Youth are Recruited, Radicalized, Utilized by International and Local Militia Groups}

The militant groups are all found to be actively recruiting and utilizing youth. The ages of the young persons varies depending on the group, across all groups there were examples of school-aged young persons (kindergarten through college, or approximately between the ages of five and twenty-two) that were involved in a range of support and operational activities. 
There appear to be variations both within the groups, as well as between the different groups overseas. The young persons who have been recruited or radicalized span a range of ages and developmental stages, include both males and females, have varying skill sets and education levels, and appear to have grown up in a variety of environments. It appears that some of the groups utilize a vetting process to help identify new recruits. In some cases, the group might be looking for more educated, skilled, or committed young persons to fill a particular role in the organization (like future leaders or operational planners), while in other cases the groups appear to be interested in simply filling the ranks. (Gaomas, 2006), Vetting has occurred through the use of "gateway organizations," which have included groups similar to the Boy Scouts or through other youth organizations, such as those affiliated with universities or religious institutions. In some cases these gateway organizations are sponsored by the militant groups to "grow" future members, while in other circumstances the groups may use the organization(s) as a venue for "spotting" potential recruits. The Internet has also been used to vet potential members by testing language capabilities, specific ideological knowledge, and fervor. As mentioned above, there appear to be variations within the groups over time with respect to who is recruited. As the group's goals and situational context change, or as they are affected by retention issues and losses of members due to incarceration or death, the types of recruits they are willing to bring on may change. In some situations where groups have enjoyed broad support from the community, they have been able to be more selective about recruits. However, when support bases have lessened and/or the need for personnel has increased, it appears to have an effect on the types of persons that are recruited (i.e., the group might decide to reach out to even younger persons or persons who have less knowledge of or dedication to the group's underlying ideology.)

Individuals that appear to play a key role in recruiting youth include (but are not limited to) religious figures and teachers, as well as family members and peers. In most cases, these individuals are members or supporters of militia groups and have access to the youth, such as in schools, religious institutions, or social situations.

In regions where the militant groups have broad community endorsement, family members (who may also belong to the group) have been known to influence or encourage their son/daughter, sibling, niece/nephew, or grandchild to support the group. Likewise, friends and close social networks that are important and influential in the lives of young persons have also been a part of the radicalization or recruitment process. Teachers at the elementary, (madras), secondary and university levels have recruited or attempted to recruit students to join or support various militant groups. It is unclear whether these individuals go into the profession for the purpose of being in a position to radicalize youth, or if they take advantage of their role as a mentor to encourage recruitment or radicalization. Young persons are not always recruited by others. In some instances, youth appear to become acquainted with the group or radicalized of their own volition. The Internet has been used by some youths to familiarize themselves with radical ideology, or to identify other likeminded persons (to include recruiters) that can provide additional information and access. 


\section{Recruiting Grounds for Radicalization}

Recruitment takes place across a wide range of venues. Common settings used by the groups schools and afterschool activities, religious institutions or events, refugee camps, and the Internet. (Godwin, 2001).For Boko Haram and al shabab, the education system like schools, religious institutions are used in some form or another to recruit or radicalize young students. Militant organizations run education system, to include infiltration in teacher and student unions, and exert total control over curricula. In other locations, groups established or taken over individual mosques to teach radical ideology and provide training. In some rural areas, these groups provided the only educational institution available to young persons. In all cases, the ability of the militant groups to gain access to schools appear to be due to weak governmental control of security over the education institutions. (Duffy, 2005).

The Internet offers thousands of sites, which provide radical propaganda distributed by militant groups, to reach potential supporters or recruits. All of the groups have Internet websites, although the extent to which they are online varies greatly. (Dierks, 2000), A trend that is noted across many of the groups is that they do not limit recruitment to local venues, but also recruit globally through some of the locations described above. There is evidence of coordination outreach to young persons in the groups' Diaspora communities. This occurs through the Internet as well as in person, with group members utilizing mosques and social activities in other locations to find sympathetic youth that could enable expansion of the group's reach.

\section{Method of Recruitment for Radicalization}

Four broad categories were identified to describe the way in which young persons were recruited or became members of the groups studied. These approaches - "born into a radical environment," forced into it, recruited or persuaded, and self-radicalization - are not inclusive of all the ways in which young persons are recruited, and are likely to occur in various combinations. To clarify, saying that some young persons are "born into a radical environment" is not to say they are "born a militant." For some of the groups and regions studied, there is a culture of violence that is reinforced by the community, and many within the community are members or supporters of the group. In situations where the group serves as the pseudo- government, providing social services and other support mechanisms, it appears the local community views membership or martyrdom on behalf of the group to be an honor, even if it means young lives are lost. (Graig, 2001). There are also some regions that have been faced with instability for years and, as a result, the only life young persons have ever known is one defined by violence and conflict. In these situations, it appears youth could be more inclined - or have no choice - to support the violent tactics used by the group. In some cases, young persons have been forced into joining or supporting militant groups. Young persons have been kidnapped from locations such as schools and refugee camps. Additionally, some youth have been forced to participate against their will or unknowingly. As described throughout this study, there are persons within all of the groups studied who have made concerted efforts to recruit or persuade youth to join or support the group's cause. Recruitment occurs in a variety of locations and utilizes a range of approaches and tactics. In some cases, recruiters will place themselves within large groups of young persons (e.g., at mosques or schools), where they will attempt to "spot" 
potential recruits to pull into smaller settings for additional indoctrination of training. Groups have also established or used gateway organizations (e.g., scouting groups) that provide access to young persons who support (or can be grown to support) the group's cause. The Internet has also enabled some youth to become self-radicalized. This forum provides access to a wealth of materials and propaganda put out by militant groups or their supporters. These websites also enable young persons to communicate anonymously with likeminded individuals and can facilitate introductions to persons with whom the youth otherwise would not have likely come in contact. For all of the groups studied, another important factor in how they recruit is the communication of tailored messages and targeting of specific grievances aimed at encouraging youth to support the cause. All of the groups took actions as a recruitment tool to manipulate young persons' personal and political grievances and/or to exploit feelings of social or cultural repression.

\section{Purpose of Recruitment for Radicalization}

While it is difficult to say exactly what youth are recruited to do, there are examples from each of the groups studied that show how young persons have been utilized. The roles include both operational and support activities, in addition to helping to keep the organization alive. Specifically, school-aged youth have been used to carry out militant attacks or serve on the front line in battles against the opposing forces. It appears that the groups use youth to support operations because they are more likely to evade detection by security forces. In some instances, it also seems that young persons are perpetrating attacks for the groups because there are not enough willing adults. Young persons were also found to fulfill a range of logistical support needs for the groups. These activities include: conducting surveillance, assisting in fundraising, or helping to move materials or weapons. Ultimately, it would appear that youth are recruited by militant groups in an attempt to keep the organization alive. To that end, young persons are utilized to keep the group's message going. (Fall, 2003). This occurs online (which may also be selfinitiated) and through youth participation in videos and other forms of propaganda. In the course of this research, several videos were identified that portray young person straining for militant activities, espousing radical ideology, and advocating youth involvement and support for the groups studied, all of which could be used as tools designed to encourage participation of other youngsters.

\section{Radicalization Benefits and Consequences}

The benefits and consequences of recruitment can be broken into two categories: those that benefit the terrorist group, and, those that benefit the young person. (Duffy, 2001).For the groups studied, the primary benefit of recruiting youth is that it enables them to fill their ranks, which is crucial to their continued existence. Duffy argues that the use of young persons help some groups evade detection by security forces, something that would enable them to carry out attacks. It does not appear that there are significant negative consequences to groups that have utilized young persons to further their goals. For the young person, the group offers to meet needs - personal, welfare, and social - that might not already be met by their social or familial networks (Alkande, et al., 2005),. In many of the regions studied, parts of the youth population are living in poverty, lack shelter and food, and have limited access to education. The terrorist groups have used these situations to their advantage by offering young persons what they are lacking (or by offering a "way out" through martyrdom). (Fall, 2003).Not all youth who have been susceptible to recruitment and radicalization necessarily come from poverty-stricken areas or conflict zones or are uneducated. Membership in terrorist groups can also help to provide a sense of community, 
family, or friendships that some young persons, rich or poor, might lack. (Clapham, 2001).Membership in groups also appeared to provide youth with a sense of identity, prestige or pride, acceptance, responsibility, outlets for frustration, and excitement -all factors that could just as easily lead youth to other types of violent or non-violent groups or networks. (Held, Det al, 1999),

\section{Conclusion and Recommendations}

Counter-recruitment/radicalization initiatives should be tailored locally by engaging community members and other stakeholders to address specific underlying factors and identify potential radicalization indicators. These initiatives must evolve with the youths through revised curriculum that can be adopted along with the dynamic technology that can address changes within environments as the youths are highly vulnerable in this $21^{\text {st }}$. century. For this reason, the study recommends that:-

i. A National Monitoring and Regulating Body to regulate preaching and religious teachings should be created to control religious activities in the country.

ii. Update Curricula that inculcate skills for employment creation and peace education that has capacity to mitigate radicalization propaganda.

iii. Economy be expanded to create more job opportunities in rural areas, tackle historical injustices that could be leading young persons to extremism; develop rehabilitation centers and programs for young persons who have been implicated in extremist activities. in addition, design programs that can provide destitute children/ street urchins with skills and attitudes to effectively participate in building Kenyan society.

iv. more resources in peace promotion and reorientation programs be put in place to emphasize on coexistence themes through Radio, Television and Film programs in the Official, National and Native Languages designed to specifically counter the narratives and messages promoting youth radicalization.

\section{References}

Alkande, M., C.F. Ponce \& Y. Curonisy (2005), Peace Parks In the Cordillera Del Cóndor Mountain Range and Bodiversity Conservation Corridor, paper submitted at workshop on Parks for Peace or Peace for Parks? Issues in Practice and Policy 12 September. Washington, D.C.:

Amnesty International, (2013).intergrating Youth education in the $21^{\text {st }}$ century. San Francisco.

Anyang'-Nyong'o, P., ed., (1990), Regional Integration inAfrica, an Unfinished Agenda.Nairobi: African Academy of Science Publications.

Clapham, C., (2001).Rethinking African states.African Security Review10(3): 7-16. Online available at: www.iss.co.za/pubs/ASR/10no3/Clapham.html. 
Dierks, K. (2000), History of the Walvis Bay and the off-shore islands origin and rise of the colonial dispute. Online available at: www.klausdierks.com/Walvis\%20Bay/index.html. Downing, D.

Demhardt, I.J. (1990), Namibia's Orange River boundary - origin and reemerged effects of an inattentive colonial boundary delimitation". Geojournal22(3): 355-362.

Draper, M., M. Spierenburg\& H. Wels (2004).African Dreams Of Cohesion: Elite Pacting And Community Development InTransfrontier Conservation Areas.OUP.

Duffy, R., (2001) Globalization and the Environment.The politics of peace parks in central America, paper presented at the 7 th International Interdisciplinary Conference on the Environment, International Environmental Association. San Francisco, 2-4 July.

Duffy, R. (2005), Global Politics and Prace Parks, paper submitted at workshop on Parks for Peace or Peace for Parks? Issues in Practice and Policy. Washington, DC: Woodrow Wilson International Center for Scholars, 12 September, online available at: www.wilsoncenter.org/events/docs/Duffy.pdf.

Fall, J.J. (2003), Drawing The Line: Boundaries, Identity and Cooperation In TBPAs, unpublished PhD Thesis. Geneva: University of Geneva.

Gaomas, S. (2006), “Africa: BordersPost To Re-Open", New Era 28 November. Online available at: ww.newera.com.na/archives.php?id=14080.

Ghai, Y. (2003), Territorial Options. In: J. Darby \& R. MacGinty, eds., Contemporary peacemaking.conflict, violence and peace processes. Basingstoke: Palgrave-Macmillan.

Godwin, P., (2001). Without Borders: Uniting Africa's PopulationsReserve. National Geographic September 2001,

GOK, (2012).The Mungiki Menace in Central Kenya.Nairobi.

Griggs, R.A. (2000), Boundaries and Peace-Building in Africa: The Spatial Implications of the 'African Renaissance.IBRU Boundary and Territory BriefingsCambridge.

Graig, A. (2001), "The Politics of Deceit", theEconomist.Windhoek, 12 October. Namibia.

Hammelburg, N. (2006), Nature Parks to Keep the Peace, 15 March.

Online available at: http://213.206.88.17/index.php?page=_contentfilter\&articleld=7876.

Hanks, J. (2001), Transfrontier-Conservation Areas (Tfcas) In Africa: Their Role In Conserving Biodiversity, Socioeconomic Development and Promoting a Culture of Peace".Journal of Sustainable Forestry. 
Hearns, G. (1997), TransboundaryProtected Area Coordination: The Experiences In Central America and Opportunities inTheSouth ChinaSea". In: G. Blake, et al., eds., International boundaries and environmental security, fameworks for regional co-operation. Londonpp. 229-248.

Held, Det al, Mcgrew, D. Goldblatt\& J. Perraton (1999), Global Transformations.Cambridge: Polity Press.

Hentz, J.J. (2004), “Africa andThe Political Economy of Regional Cooperation Journal of Modern African Studies.

Sifuna, (2006), The Map of Africa by Treaty, 3rd edition (reprinted). London.

International Boundary Research Unit (2006), Website: www.dur.ac.uk/ibru.

International Humanitarian Law, (2005).International Boundaries and Peace-Building Practices: A Global Concern.page=_contentfilter\&articleld=7876.Cambridge: Polity Press.

IRIN, (2013).Global Boundaries and Peace-Building: The spatial implications of the 'African Renaissance. Washington DC.

UNICEF Report, (2010), Conflict and the Development Agenda. Geneva. 